\title{
Flow Cytometry in the Study of Cell Death
}

\author{
Álvaro L Bertho ${ }^{+}$, Marta A Santiago, Sérgio G Coutinho
}

Laboratório de Imunidade Celular e Humoral, Departamento de Protozoologia, Instituto Oswaldo Cruz, Av. Brasil 4365, 21045-900 Rio de Janeiro, RJ, Brasil

In this report we present a concise review concerning the use of flow cytometric methods to characterize and differentiate between two different mechanisms of cell death, apoptosis and necrosis. The applications of these techniques to clinical and basic research are also considered. The following cell features are useful to characterize the mode of cell death: (1) activation of an endonuclease in apoptotic cells results in extraction of the low molecular weight DNA following cell permeabilization, which, in turn, leads to their decreased stainability with DNA-specific fluorochromes. Measurements of DNA content make it possible to identify apoptotic cells and to recognize the cell cycle phase specificity of apoptotic process; (2) plasma membrane integrity, which is lost in necrotic but not in apoptotic cells; (3) the decrease in forward light scatter, paralleled either by no change or an increase in side scatter, represent early changes during apoptosis. The data presented indicate that flow cytometry can be applied to basic research of the molecular and biochemical mechanisms of apoptosis, as well as in the clinical situations, where the ability to monitor early signs of apoptosis in some systems may be predictive for the outcome of some treatment protocols.

Key words: apoptosis - flow cytometry - cell death - necrosis

The two modes of cell death, apoptosis and accidental cell death (necrosis), differ fundamentally in their morphology, biochemistry and biological relevance (Majno \& Joris 1995). Depending on the cell type and the stimulus, a cell may die by either of these two distinct ways. Necrosis, a nonspecific mode of cell death, is characterized by swelling of the cell and the mitochondria, which results in disruption of the cell membrane and in lysis (Schrek et al. 1980, Kerr \& Harmon 1991). Release of the cytoplasmic content leads to an inflammatory response.

Apoptosis appears to be an active process that plays a role in tissue and organ development (Lockshin \& Zakeri 1991), regulation of immune responses (Duke 1991, Abbas et al. 1997, Cohen 1999), or natural death of differentiated cells at the end of their life span (Lockshin \& Zakeri 1991). Accurate identification and quantification of the mode of cell death occurring in a particular situation is a necessary prerequisite to an understanding of the biological process taking place. Apoptosis can be defined by morphological criteria, including chromatin condensation and margination, cell shrinkage, membrane blebbing, and formation of apoptotic

\footnotetext{
Corresponding author. Fax: +55-21-598.4247. Email: bertho@fiocruz.br Received 30 August 1999 Accepted 9 February 2000
}

bodies (Darzynkiewicz et al. 1992, Dive et al. 1992). Apoptosis is also characterized biochemically by enzymatic internucleosomal DNA destruction (Catchpoole \& Stewart 1995, Darzynkiewicz et al. 1997). Unfortunately, both morphological and biochemical evaluation of apoptosis lack accurate quantification and sensitivity. While cell death identification has exclusively relied upon light or electron microscopy (Walker et al. 1988, Fesq et al. 1994), methods used for quantitation have included microscopy (Searle et al. 1982), colony-formation assays (Pollack \& Ciancio 1989), vital dye exclusion tests (Hudson \& Hay 1986) and flow cytometry (Nicoletti et al. 1991, Darzynkiewicz et al. 1992, 1997, Schmid et al. 1994a,b, Vermes et al. 1995, Douglas et al. 1998).

The capacity of flow cytometry for rapid, individual analysis of a large number of cells would appear to make it ideally adapted for the study of cell death. Several flow cytometry methods are available that primarily use alterations in DNA, light scatter properties, or surface membrane to assess cell death (Koopman et al. 1994, Schmid et al. 1994b, Darzynkiewicz et al. 1997, Ferlini et al. 1997). Thus, apoptotic cells can be recognized by their diminished stainability with DNA specific fluorochromes such as propidium iodide (PI) (Fig. 1), DAPI, acridine orange, or Hoechst dyes, due to DNA degradation and its subsequent leakage from the cell. In contrast to apopotic cells, necrotic cells generally do not show an immediate reduction in DNA stainability. Thus, the discrimination between normal live or necrotic cells is impossible based 
on single-parameter DNA content analysis alone. Changes in the morphology of cells undergoing apoptosis affect their light scattering properties. The decrease in forward light scatter can be observed in thymocytes triggered to undergo apoptosis, paralleled by an increase in side scatter. Cell death by necrosis results in a increase of the forward and side scatter signals. The integrity of the plasma membrane of cells undergoing apoptosis is preserved and most functions of the membrane remain unchanged (Arends et al. 1990). Apoptotic cells, thus, exclude "viability assay" dyes such as trypan blue or PI. This is in contrast to necrotic cells, in which one of the earliest changes is the loss of membrane function and its structural integrity. By their ability to exclude PI, apoptotic cells can be erroneously classified by flow cytometry as viable cells. To evaluate apoptosis in a mixed cell population, identification of cell phenotype is necessary. Several currently available techniques allow phenotypic discrimination of cell populations and simultaneous quantification of apoptosis (Telford et al. 1992, Schmid et al. 1994a, Sherwood \& Schimke 1995, Chiu et al. 1996). An assay of cell viability based on simultaneous cell staining with PI and HOECHST 33342 (HO342) provides a means to discriminate between live vs apoptotic vs necrotic cells (Pollack \& Ciancio 1991). PI has been the stain most often used to determine apoptotic events, however it produces staining overlap with PE. Additionally, the cell membrane must be permeabilized and therefore can not be stained for surface markers. Some methods use HO342 for measurement of DNA content or apoptosis, however, this dye requires UV excitation which hinders its general use. Furthermore, PI and HO 342 can compromise the simultaneous assessment of cell cycle or aneuploidy. Measurements of cell cycle or aneuploidy can be vital for investigations in tumor systems. In this context, Douglas et al. (1998) described a new approach for simultaneous evaluation of cell phenotype, apoptosis and cell cycle using the TUNEL method (previously described by Gavrieli et al. 1992) to determine apoptosis, while cell cycle information was assessed with an ultraviolet DNA binding dye, DAPI. To simultaneously determine surface phenotype they combined with FITC- and PE-labeled surface antibodies. Nevertheless the use of three-laser instrumentation prevents its customary use. Another assay which combines the staining with annexin $\mathrm{V}$ and PI has been used to discriminate early apoptotic cells from late apoptotic and necrotic ones, based on the determination of the translocation of phosphatidyl serine from the inner to the outer layer of the plasma membrane of early apoptotic cells, stained by annexin V (Vermes et al. 1995).

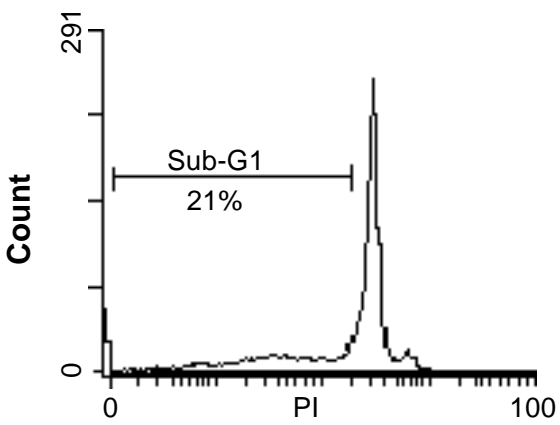

Fig. 1: analysis of apoptosis by hypotonic PI staining method. In this experiment cells were cultured in the presence of Staurosporine for three days to induce early apoptosis and then stained by the hypotonic PI assay. The sub-G1 region encompasses the apoptotic cells.

Inaccurate apoptosis determinations can be readily overcome by simultaneous cell surface staining of apoptotic cells. The acridine orange/ ethidium bromide (AO/EB) assay cannot be used for phenotypic analyses due to broad emission spectrum of AO and EB. The in situ nick translation (ISNT) assay permits phenotypic measurements on apoptotic cells (Meyaard et al. 1994), but we ascertained that an underestimation of apoptosis could occur in some subsets due to a decrease in cell surface antigen expression associated with apoptosis (Swat et al. 1991, Schmid et al. 1994a,b) and ethanol fixation (Lecoeur \& Gougeon 1996). In fact, the more reliable method to identify the cell subsets involved in the apoptosis process is the combination of 7-AAD staining with FITC or PE cell surface staining (Schmid et al. 1992, 1994 a,b). Nevertheless, Lecoeur and Gougeon (1996) have showed that erythrocytes can significantly interfere in the 7-AAD assay because of their size which is similar to lymphocytes. However this interference could be easily avoided by targeting the apoptotic cells with appropriated cell surface monoclonal antibodies, such as CD45.

\section{APPLICATIONS IN HUMAN DISEASES}

Regarding apoptosis, it has been hypothesized that this phenomenon may represents an important modulatory mechanism. In this connection, several studies in Aids patients have suggested that apoptotic events occurring in $\mathrm{CD}^{+}$and/or $\mathrm{CD} 8^{+}$ $\mathrm{T}$ lymphocytes may aggravate the progression of the disease (Gougeon et al. 1993, 1996, Ameisen et al. 1995, Echaniz et al. 1995, Neves Jr. et al. 1998). Several viruses are known to induce apoptosis, as exemplified by infection of human peripheral monocytes with dengue- 1 and dengue2 viruses (von Sydow et al. 1998). 
Several flow cytometric techniques have been used on the studies about the occurrence of cell death in protozoan diseases (reviewed by Barcinski $\&$ DosReis 1999). Some works have also focused on its possible role in the aggravation of experimental Chagas disease (Lopes \& DosReis 1995, 1996). Activation-induced cell death of $\mathrm{CD}^{+}{ }^{+} \mathrm{T}$ cells from Trypanosoma cruzi infected mice abrogate IFN- $\gamma$ production and up-regulates parasite replication in macrophages in vitro (Nunes et al. 1998). In leishmaniasis there is evidence suggesting that the sensitivity of Leishmania promastigotes to programmed cell death (PCD) is induced by heat shock and modulated by calcium (Moreira et al. 1996). It has also been demonstrated that the intracellular infection by L. donovani inhibited PCD in macrophages (Moore \& Matlashewski 1994).

Human localized cutaneous leishmaniasis (LCL) induced by L. braziliensis, ranges from a clinically mild, self-healing disease with localized cutaneous lesion to severe forms, which can involve secondary metastatic lesions. T-cell-mediated immune response is extremely important to define the outcome of the disease; however, the underlying mechanisms involved are not fully understood. We adapted a 7-AAD assay in combination with $\mathrm{CD}^{+}$or $\mathrm{CD}^{+} \mathrm{T}$ cell surface phenotyping

a
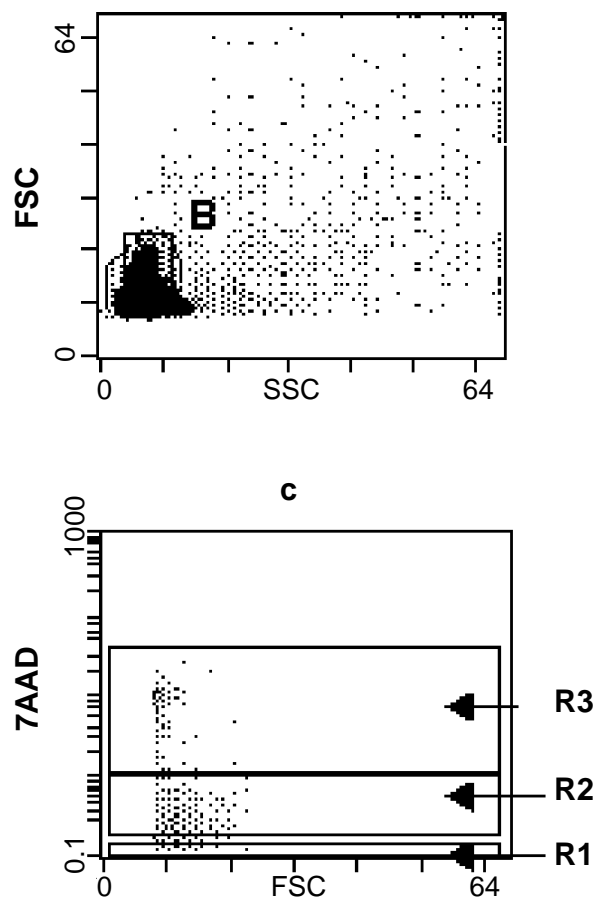

to verify whether different levels of early apoptosis or late apoptosis and accidental cell death were found at different stages of LCL lesions (Fig. 2). When cells, separated from a biopsy sample and displaying normal viability patterns, were gated, higher levels of early apoptotic and dead cells were observed in lesions from patients with active disease as compared with lesions on spontaneous healing. Hence, higher levels of early apoptotic cells were detected among $\mathrm{CD}^{+} \mathrm{T}$ cells as compared with $\mathrm{CD}^{+} \mathrm{T}$ cells from patients with active disease. These data suggest that higher proportions of cell death events in $\mathrm{CD}^{+} \mathrm{T}$ cells from patients with LCL would be associated with active disease. Interestingly, it was observed low amounts of early apoptotic events among $\mathrm{CD}^{+} \mathrm{T}$ cells derived from patients with self healing lesions (Fig. 3). It is possible to speculate that, during the immune response, differences in apoptotic events in $\mathrm{CD} 4^{+}$and $\mathrm{CD} 8^{+}$ $\mathrm{T}$ cell subsets could be responsible for changing the CD4/CD8 balance, thus leading to healing or maintenance of disease (Bertho et al. 2000).

\section{THE FUTURE}

It seems probable that the future applications of flow cytometry to studies of apoptosis could develop in three ways. The first direction would
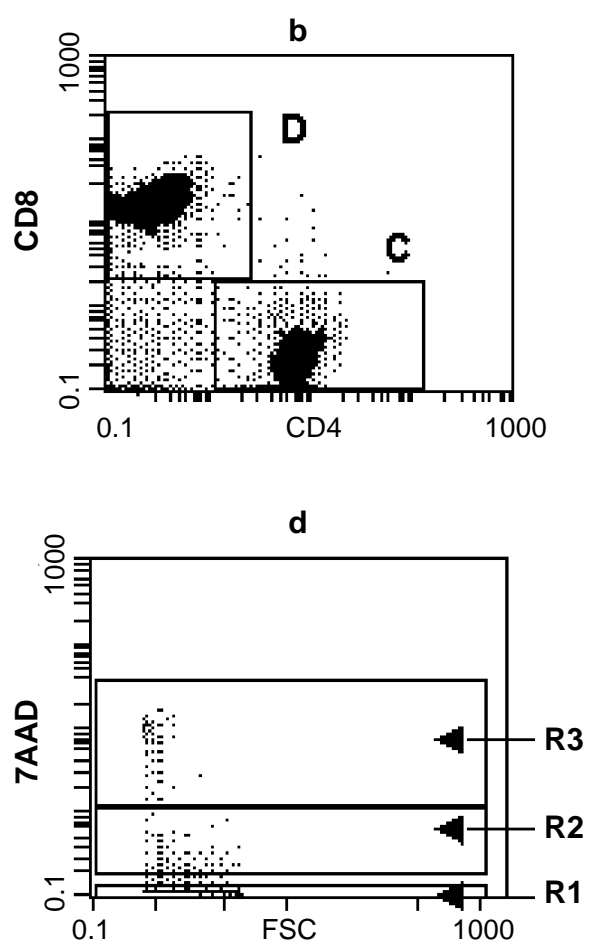

Fig. 2a: representative flow cytometric analysis to determine live (R1), early apoptotic (R2) or dead (ACD) (R3) $\mathrm{CD}^{+}$or $^{\mathrm{CD}} 4^{+} \mathrm{T}$ cells, obtained from lesion of localized cutaneous leishmaniasis patient. a: scatter histogram (SSC/FSC) in which gate $B$ were created, following viability scatter patterns; $b$ : dual-color dot plot of $\mathrm{CD}^{+}-\mathrm{PE}$ and CD4 ${ }^{+}$-FITC T cells based on gate B; c: FSC vs. 7-AAD gated on $\mathrm{CD}^{+} \mathrm{T}$ cells within gate $\mathrm{D}$; d: FSC vs. 7-AAD gated on $\mathrm{CD} 4^{+} \mathrm{T}$ cells within gate $\mathrm{C}$. 


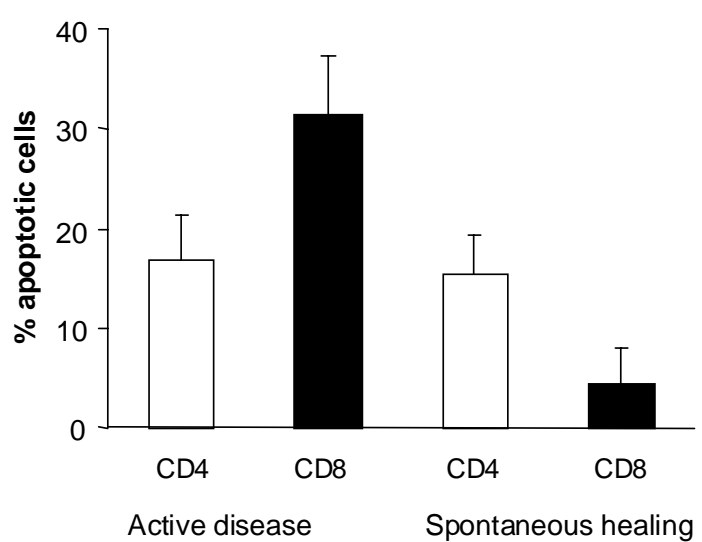

Fig. 3: early apoptotic in $\mathrm{CD} 4^{+}$or $\mathrm{CD}^{+} \mathrm{T}$ cells obtained from lesions of patients with active disease or spontaneous healing as measured by flow cytometry. Solid bars represent early apoptotic $\mathrm{CD}^{+} \mathrm{T}$ cells, and open bars, early apoptotic $\mathrm{CD} 4^{+} \mathrm{T}$ cells. $(P=0.0001) ;(P=0.0004)$.

be in the field of cellular and molecular biology and pharmacology. It would involve further investigation of various metabolic features of cells undergoing apoptosis, to better comprehend the mechanisms of this process. A diversity of markers can be used to reveal molecular changes that occur in the sequence of events that lead to DNA degradation and cell death. The second area in which flow cytometry would prove useful is more related to the clinic. This methodology offers promise for the early detection of apoptotic cells in tumors during treatment. Sampling of tumors for apoptotic cells may offer a very early marker of tumor response, predictive of cancer's sensitivity to a given treatment. The third application is to immunological studies concerning the pathogenesis of a variety of human diseases including protozooses (such as Chagas disease, leishmaniasis, toxoplasmosis and leprosis), cancer, autoimmune diseases, neurodegenerative disorders, Aids and viral infections, such as dengue. There are many aspects which should be investigated to better understand the mechanisms involved in the pathogenesis of these diseases.

\section{REFERENCES}

Abbas AK, Lichtman AH, Pober JS 1997. Functional anatomy of immune responses. In AK Abbas, $\mathrm{AH}$ Lichtman \& JS Pober (eds), Cellular and Molecular Immunology, WB Saunders Company, USA, p. 233246.

Ameisen JC, Estaquier J, Idziorek T, De Bels F 1995. The relevance of apoptosis to AIDS pathogenesis. Trends in Cell Biol 5: 27-31.

Arends MJ, Morris RG, Wyllie H 1990. Apoptosis: The role of endonuclease. Am J Pathol 136: 593-608.

Barcinski MA, DosReis GA 1999. Apoptosis in para- sites and parasite-induced apoptosis in the host immune system: a new approach to parasitic disease. Braz J Med Biol Res 32: 395-401.

Bertho AL, Santiago MA, Da-Cruz AM, Coutinho SG 2000. Detection of early apoptosis and cell death in $\mathrm{T}$ CD4+ and CD8+ cells from lesions of localized cutaneous leishmaniasis patients. Braz J Med Biol Res 33 (in press).

Catchpoole DR, Stewart BW 1995. Formation of apoptotic bodies is associated with internucleosomal DNA fragmentation during drug-induced apoptosis. Exp Cell Res 216: 169-177.

Chiu I, Cheewinski H, Ransom J, Dunne JF 1996. Flow cytometric ratio analysis of the Hoechst 33342 emission spectrum: Multiparametric characterization of apoptotic lymphocytes. J Immunol Methods 189: 157-171.

Cohen JJ 1999. Apoptosis: mechanisms of life and death in the immune system. J Allergy Clin Immunol 103: 548-554.

Darzynkiewicz Z, Bruno S, Del Bino G, Gorczyca W, Hotz MA, Lassota P, Traganos F 1992. Features of apoptotic cells measured by flow cytometry. Cytometry 13: 795-808.

Darzynkiewicz Z, Juan G, Li X, Gorczyca W, Murakami T, Tragands F 1997. Cytometry in cell necrobiology: Analysis of apoptosis and accidental cell death (necrosis). Cytometry 27: 1-20.

Dive C, Gregory CD, Phipps DJ, Evans DL, Milner AE, Wyllie AH 1992. Analysis and discrimination of necrosis and apoptosis (programmed cell death) by multiparameter flow cytometry. Biochem Biophys Acta 1133: 275-285.

Douglas RS, Pletcher Jr CH, Nowell PC, Moore JS 1998. Novel approach for simultaneous evaluation of cell phenotype, apoptosis, and cell cycle using multiparameter flow cytometry. Cytometry 32: 57-65.

Duke RC 1991. Apoptosis in cell-mediated immunity. In LD Tomei \& FO Cope (eds), Apoptosis: The Molecular Basis of Cell Death. Curr Commun Cell \& Mol Biol, Vol. 3, Cold Spring Harbor Laboratory Press, Cold Spring Harbor, New York, p. 209-226.

Echaniz P, De Juan MD, Cuadrado E 1995. DNA staining changes associated with apoptosis and necrosis in blood lymphocytes of individuals with HIV infection. Cytometry 19: 164-170.

Ferlini C, Kunkl A, Scambia G, Fatorossi A 1997. The use of Apostain in identyfing early apoptosis. $J$ Immunol Methods 205: 95-101.

Fesq H, Bacher M, Nain M, Gemsa D 1994. Programmed cell death (apoptosis) in human monocytes infected by influenza A virus. Immunobiology 190: 175-182.

Gavrieli Y, Sherman Y, Ben-Sasson AS 1992. Identification of programmed cell death in situ via specific labeling of nuclear DNA fragmentation. J Cell Biol 119: 493-501.

Gougeon ML, Garcia S, Heeney J, Tchopp R, Leconeur H, Guetard D, Rame V, Dauguest C, Montaignier L 1993. Programmed cell death in AIDS - related HIV and SIV infections. AIDS Res Hum Retroviruses 9: 553-558.

Gougeon ML, Lecoeur H, Dulioust A, Enouf MG, 
Crouvoiser M, Goujard C, Debord T, Montagnier L 1996. Programmed cell death in peripheral lymphocytes from HIV-infected persons: Increased susceptibility to apoptosis of CD4 and CD8 T-cells correlates with lymphocyte activation and disease progression. J Immunol 156: 3509-3520.

Hudson L, Hay FC 1986. Practical Immunology, 2nd ed., Blackwell Scientific Publications, Oxford, p. 29-31.

Kerr JFR, Harmon BV 1991. Definition and incidence of apoptosis: An historical perspective. In LD Tomei \& FO Cope (eds), Apoptosis: The Molecular Basis of Cell Death. Curr Commun Cell \& Mol Biol, Vol. 3, Cold Spring Harbor Laboratory Press, Cold Spring Harbor, New York, p. 5-29

Koopman G, Reutelingsperger CP, Kuijten GA, Keehnen RM, Pals ST, van Oers MH 1994. Annexin V for flow cytometric detection of phosphatidylserine expression on B cells undergoing apoptosis. Blood 84: 1415-1420.

Lecoeur H, Gougeon ML 1996. Comparative analysis of flow cytometric methods for apoptosis quantitation in murine thymocytes and human peripheral lymphocytes from controls and HIV-infected persons. Evidence for interference by granulocytes and erythrocytes. J Immunol Methods 198: 87-99.

Lockshin RA, Zakeri Z 1991. Programmed cell death and apoptosis. In LD Tomei \& FO Cope (eds), Apoptosis: The Molecular Basis of Cell Death. Curr Commun Cell \& Mol Biol, Vol. 3, Cold Spring Harbor Laboratory Press, Cold Spring Harbor, New York, p. 47-60.

Lopes MF, DosReis GA 1995. Apoptosis as a cause of T-cell unresponsiveness in experimental Chagas' disease. Braz J Med Biol Res 28: 913-918.

Lopes MF, DosReis GA 1996. Trypanosoma cruzi-induced immunosupression: selective triggering of CD4+ T-cell death by the T-cell receptor-CD3 pathway and not by the CD69 or Ly-6 activation pathway. Infect Immun 64: 1559-1564.

Majno G, Joris I 1995. Apoptosis, oncosis, and necrosis. An overview of cell death. Am J Pathol 146: 3-15.

Meyaard L, Otto SA, Keet IP, Roos MT, Miedema F 1994. Programmed death of T cells in human immunodeficiency virus infection. No correlation with progression to disease. J Clin Invest 93: 982-986.

Moore RJ, Matlashewski G 1994. Intracellular infection by Leishmania donovani inhibits macrophage apoptosis. J Immunol 152: 2930-2936.

Moreira MEC, Del Portillo HA, Milder RV, Balanco JMF, Barcinski MA 1996. Heat shock induction of apoptosis in promastigotes of the unicellular organism Leishmania (Leishmania) amazonensis. J Cell Physiol 167: 305-313.

Neves Jr I, Bertho AL, Veloso VG, Nascimento DV, Campos-Mello DLA, Morgado MG 1998. Improvement of the lymphoproliferative immune response and apoptosis inhibition upon in vitro treatment with zinc of peripheral blood mononuclear cells (PBMC) from HIV+ individuals. Clin Exp Immunol 111: 264-268.

Nicoletti I, Migliorati G, Pagliacci MC, Grignani F, Riccardi C 1991. A rapid and simple method for measuring thymocyte apoptosis by propidium iodide staining and flow cytometry. J Immunol Methods 139: 271-279.

Nunes MP, Andrade RM, Lopes MF, DosReis GA 1998. Activation-induced T-cell death exacerbates T. Cruzi replication in macrophages cocultured with CD4+ T lymphocytes from infected hosts. J Immunol 160: 1313-1319.

Pollack A, Ciancio G 1989. Multiparameter cell cycle analysis of G2-arrest and cell death following ionizing irradiation. In A Yen, Flow Cytometry: Advanced Research and Clinical Applications, Vol. II, CRC Press, Boca Raton, p. 29-47.

Pollack A, Ciancio G 1991. Cell-cycle phase-specific analysis of cells viability using Hoechst 33342 and propidium iodide after ethanol preservation. In $\mathrm{Z}$ Darzynkiewicz \& HA Crissman (eds), Flow Cytometry, Academic Press, San Diego, p. 19-24.

Schmid I, Krall WJ, Uittenbogaart CH, Braun J, Giorgi JV 1992. Dead cell discrimination with 7-amino-actinomycin D in combination with dual color immunofluorescence in single laser flow cytometry. Cytometry 13: 204-208.

Schmid I, Uittenbogaart CH, Giorgi JV 1994a. Sensitive method for measuring apoptosis and cell surface phenotype in human thymocytes by flow cytometry. Cytometry 15: 12-20.

Schmid I, Uittenbogaart CH, Keld B, Giorgi JV 1994b. A rapid method for measuring apoptosis and dualcolor immunofluorescence by single laser flow cytometry. J Immunol Methods 170: 145-157.

Schrek R, Chandra S, Molnar Z, Stefani S 1980. Two types of interphase death of lymphocytes exposed to temperatures of 37-45 C. Radiat Res 82: 162-170.

Searle J, Kerr JFR, Bishop CJ 1982. Necrosis and apoptosis: Distinct modes of cell death with fundamentally different significance. Pathol Annu 17: 229-259.

Sherwood SW, Schimke RT 1995. Cell cycle analysis of apoptosis using flow cytometry. Methods Cell Biol 46: 77-97.

Swat W, Ignatowicz L, Kisielow P 1991. Detection of apoptosis of immature $\mathrm{CD} 4^{+} 8^{+}$thymocytes by flow cytometry. J Immunol Methods 137: 79-85.

Telford WG, King LE, Fraker PJ 1992. Comparative evaluation of several DNA binding dyes in the detection of apoptosis-associated chromatin degradation by flow cytometry. Cytometry 13: 137-143.

Vermes I, Haanen C, Steffens-Nakken H, Reutelingsperger CP 1995. A novel assay for apoptosis. Flow cytometric detection of phosphatidyl serine expression on early apoptotic cells using fluorescein labeled Annexin V. J Immunol Methods 184: 39-45.

von Sydow FFO, Bertho A, Santiago M, Gouvea AS, Neves-Souza PC, Lavatori MFH, Kubelka CF 1998. Infection of human peripheral monocytes with dengue-1 and dengue-2 strains induce apoptosis. Proceedings of International Meeting on Vaccine, Salvador, Bahia, Brazil, p. 65.

Walker NI, Harmon BV, Gobé GC, Kerr JFR 1988. Patterns of cell death. Methods Achiev Exp Pathol 13: 18-54. 